\title{
Clinical and Therapeutic Aspects of Giant Fibroids at the Hôpital du Mali about 30 Cases
}

\author{
Mamadou B. Coulibaly ${ }^{1}$, Alassane Traore ${ }^{1}$, Mody A. Camara ${ }^{2}$, Abdrahamane Togo', \\ Adama Sangaré1, Issa Ongoiba', Kalba Timbine ${ }^{3}$, Amadou Sidibé ${ }^{3}$, Apérou Guindo1, \\ Niani Mounkoro4, Ibrahim Teguete ${ }^{4}$, Youssouf Traore ${ }^{4}$, Moustaphe Toure ${ }^{1}$
}

${ }^{1}$ Service of Gynecology of the Hôpital du Mali, Bamako, Mali

${ }^{2}$ Service of Medical Imaging of the Hôpital du Mali, Bamako, Mali

${ }^{3}$ Service of Anesthesia and Resuscitation of the Hôpital du Mali, Bamako, Mali

${ }^{4}$ Service of Gynecology-Obstetrics of Gabriel TOURE Teaching Hospital, Bamako, Mali

Email: *mbccolby1@yahoo.com

How to cite this paper: Coulibaly, M.B., Traore, A., Camara, M.A., Togo, A., Sangaré, A., Ongoiba, I., Timbine, K., Sidibé, A., Guindo, A., Mounkoro, N., Teguete, I., Traore, Y. and Toure, M. (2020) Clinical and Therapeutic Aspects of Giant Fibroids at the Hôpital du Mali about 30 Cases. Open Journal of Obstetrics and Gynecology, 10, 778-789.

https://doi.org/10.4236/ojog.2020.1060072

Received: May 1, 2020

Accepted: June 8, 2020

Published: June 11, 2020

Copyright ( 2020 by author(s) and Scientific Research Publishing Inc. This work is licensed under the Creative Commons Attribution International License (CC BY 4.0).

http://creativecommons.org/licenses/by/4.0/ (c) (i) Open Access

\begin{abstract}
The fibroids affect $20 \%$ to $25 \%$ of women of reproductive age and are 3 to 9 times more common in black women. We'll talk about giant fibroids (GFs) when uterine height reaches or exceeds the navel. We have initiated this study in order to report the epidemioclinical and therapeutic aspects of giant fibroids at the Hôpital du Mali. A descriptive retro-prospective study, conducted in the service of gynecology of the Hôpital du Mali from November 2017 to December 2018 were included in this study, any patients, regardless of their age, having developed a fibroid, the uterine height of the patient reaching or exceeding the umbilicus on physical examination and who were on surgical treatment. We had collected 30 cases of GFs out of the 92 patients who had undergone myomectomies, with a frequency of $32.60 \%$. The age group $25-29$ years accounted for $46.6 \%$ with an average age of 35 years. Housewives represented $50 \%$ and nulligravida made up $33 \%$ of our patients. Desire to become pregnant was the main reason for consultation in $34.4 \%$ of cases. The uterine height was between 25 and $29 \mathrm{~cm}$ on physical examination in $46.66 \%$ of cases. Myomectomy was performed in $76.64 \%$ and hysterectomy in $23.3 \%$ of cases. The size of the nuclei after surgery was over $25 \mathrm{~cm}$ in $48.66 \%$ of our patients. Conclusion: The giant fibroid (GF) is a common cause of myomectomy. The treatment is either hysterectomy or myomectomy and depends on the indications.
\end{abstract}

\section{Keywords}

Giant Fibroma, Care, Surgery, Hôpital du Mali 


\section{Introduction}

Uterine fibroids (UFs), also called uterine leiomyomas or myomas, are the most widespread benign tumors of the female genital tract. They affect $20 \%$ to $25 \%$ of women of reproductive age and are 3 to 9 times more common in black women than in white women [1]. They generally develop after the age of 30 [1] [2]. However, pathogenesis remains not fully understood today. Their occurrence and growth are influenced by many factors including: estrogens, progestins, growth factors, angiogenesis, genetic predisposition, nulliparous, obesity and early menarche [3] [4].

UFs are often asymptomatic, detected during a systematic gynecological examination or during pelvic imaging. They can develop as menometrorrhagia, heaviness, pelvic pain, a feeling of mass. They may be a matter of infertility [5].

They are usually small, ranging from a few millimeters to several centimeters, and are often asymptomatic. UFs can have large dimensions up to several decimeters. Today, fibroids constitute a real public health issue [5]. The excessive volume of certain fibroids, the delayed diagnosis and even the reluctance of certain patients to modern medicine lead to a difficulty in the various methods of treatment [4]. No study had been done in Mali in this sense. The present work was initiated in order to report the socio-demographic and therapeutic aspects of GFs in the gynecology unit of the Hôpital du Mali.

\section{Methodology}

It was a descriptive retro-prospective study about data collection. The study was conducted in the service of gynecology of the Hôpital du Mali from November 01, 2017 to December 31, 2018 were included in our study, any patient who consulted at the Mali hospital during the study period. In whom, the diagnosis of giant fibroid was made on the basis that the size of the uterus exceeded the patient's umbilicus on physical examination (on palpation). Having had a pelvic ultrasound for the measurement and topography of fibroids.

Not included in our study, any fibroid not respecting the above mentioned criteria.

The variables studied were: socio-demographic (age, marital status), gyneco-obstetrics (parity and gravidity), clinical (menstrual disorder, desire for a child, pelvic pain, pelvic masses), imaging (pelvic ultrasound), gynecological examination (vaginal examination, measurement of uterine height) preoperative biological assessment.

All of our patients had previously received a consultation. The gynecological examination was supplemented by visual inspection techniques using a speculum with acetic acid and Lugol (IVA/IVAL) for cervical cancer screening.

The uterine height was assessed with a measuring tape from the upper edge of the pubis to the upper end of the uterus via the umbilical line. This measurement was evaluated in centimeters before surgery. Measurements of the myomatous nuclei and or the uterus were evaluated post-operatively.

All patients had undergone pelvic ultrasound to assess the size and mapping 
of myomas. A preoperative biological assessment including: rhesus grouping, blood count, blood sugar, creatinemia (bleeding, coagulation, cephalin kaolin), uricemia and retroviral serology.

Surgical decisions were made on the basis of: excessive size of the uterus, menometrorrhagia and desire of pregnancy. All the patients had undergone a pre-anesthetic consultation. Our data was collected on an individual survey sheet, from patient records, the operating report register, and the pathology result.

\section{Results}

We had collected 30 cases of GFs out of 92 patients operated on for myomectomies, with a frequency of $32.60 \%$. They accounted for $8.69 \%$ of the overall surgical procedures of the service. The age group 25 - 29 years represented $46.6 \%$ of our patients with a mean age of 35 years ranging from 20 to 39 years old. Among our patients, housewives represented $50 \%$, nulligravida (33\%) and nulliparous (50\%). The reason for consultation for desire to become pregnant concerned $34.48 \%$ of our patients. The history of myomectomy was found out in $20 \%$ of the patients (Table 1). The delay of 5 years between the occurrence of the signs and the consultation had been found in $53.3 \%$ of the cases. Pelvic mass was the most common clinical sign (83.3\%). The uterine

Table 1. Sociodemographic and clinical characteristics.

\begin{tabular}{|c|c|c|c|}
\hline & & Effective $(N=30)$ & Percentage (\%) \\
\hline \multirow[t]{3}{*}{ Middle age (year) } & 35 & & \\
\hline & 0 & 10 & 33.33 \\
\hline & 1 & 8 & 26.67 \\
\hline \multirow[t]{3}{*}{ Pregnancy } & 2 & 6 & 20 \\
\hline & $\geq 3$ & 6 & 20 \\
\hline & nulliparous & 15 & 50.00 \\
\hline \multirow{5}{*}{ Parity } & primiparous & 9 & 30.00 \\
\hline & pauciparous & 4 & 13.33 \\
\hline & multiparous & 2 & 6.67 \\
\hline & Pelvic pain & 7 & 23.33 \\
\hline & Desire to be pregnant & 10 & 34.48 \\
\hline \multirow{3}{*}{ Reason for consultation } & Metrorrhagia & 7 & 24.14 \\
\hline & Mass perception & 6 & 20.69 \\
\hline & Mucosal & 56 & 18.54 \\
\hline \multirow[t]{3}{*}{$\begin{array}{c}\text { Topography of fibroids } \\
\text { on ultrasound }\end{array}$} & Interstitial & 147 & 48.67 \\
\hline & Serosal & 99 & 32.79 \\
\hline & $20-24$ & 12 & 40 \\
\hline \multirow[t]{2}{*}{$\begin{array}{c}\text { Uterus size }(\mathrm{cm}) \text { on abdominal } \\
\text { palpation }\end{array}$} & $25-29$ & 14 & 46.66 \\
\hline & $30-34$ & 2 & 6.67 \\
\hline
\end{tabular}


height (UH) between $25-29 \mathrm{~cm}$ on physical examination was observed in $46.66 \%$ of patients (Figure 1). All of our patients had a pelvic ultrasound. Interstitial myoma involved $48 \%$ of the cases (Table 1). Myomectomy and hysterectomy were performed respectively in $76.64 \%$ and $23.3 \%$ of cases (Figure 2). This poly myomectomy had been performed without opening the uterine cavity in $60 \%$ of the cases and in $40 \%$ without opening the cavity (Figure 3 and Figure 4). In our study, a weight including 1 to $5 \mathrm{~kg}$ of the nuclei and or the uterus (Figure 5) was pointed out in $80 \%$ of the patients (Table 2). The size of the nuclei or uterus measuring more than $25 \mathrm{~cm}$ after surgery was figured out in $48.66 \%$ of patients. Blood transfusion involved $26.6 \%$ pre and intra operative and $30 \%$ post operatively. Operative complications were dominated by hemorrhages in $20 \%$. No death was reported. Leiomyoma was the histological tissue found in all cases of myomectomy. The average hospital stay was 3 to 5 days. The patients were followed 12 months postoperatively, due to one outpatient visit per month.

\section{Discussions}

Frequency: There is no consensus determining the dimensions and the weight for which these fibroids would be considered giant. During our study, we defined a giant fibroid (GF) as any fibroid whose uterine height (UH) was $20 \mathrm{~cm}$ or more or exceeding the patient's navel (Figure 1).

During our study period, from November 01, 2017 to December 31, 2018, we

Table 2. Distribution by weight of the myomatous nuclei and or the uterus after surgery.

\begin{tabular}{ccc}
\hline Weight of nuclei & Frequency & Percentage \\
\hline $1-5 \mathrm{~kg}$ & 24 & 80 \\
$5.1-10 \mathrm{~kg}$ & 3 & 10 \\
$10.1-15 \mathrm{~kg}$ & 3 & 10 \\
Total & 30 & 100 \\
\hline
\end{tabular}

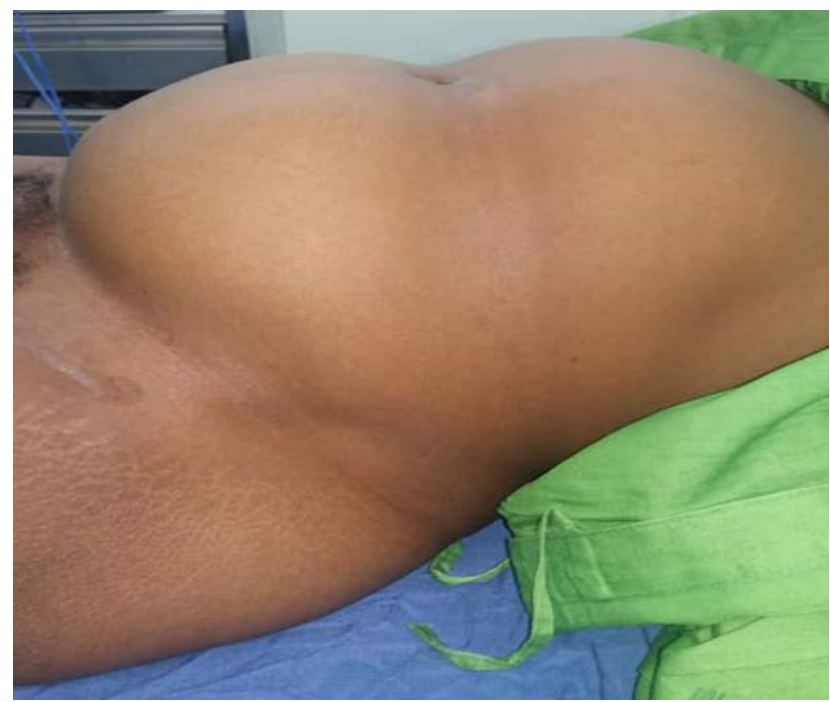

Figure 1. Increase in pelvic volume in a woman with a GF. 
collected 30 cases of GFs out of 92 myomectomies in the department, with a frequency of $32.60 \%$ and $8.69 \%$ on the overall surgical procedures of the service. Erghouni M [8] in Morocco had reported a frequency of 3\% on all of the department's surgical operations over two years. Our high frequency could be accounted for on the one hand by the position of the hospital (the only one on the right side of Bamako) and on the other hand our service is almost exclusively devoted to gynecological activity.

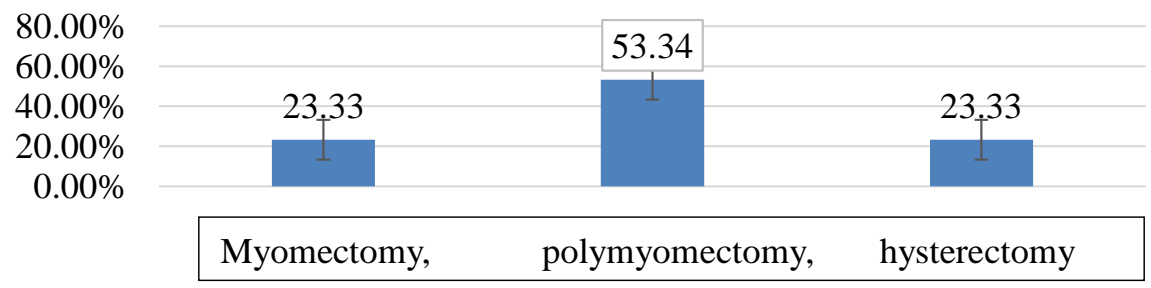

Figure 2. Distribution according to the operating indications.

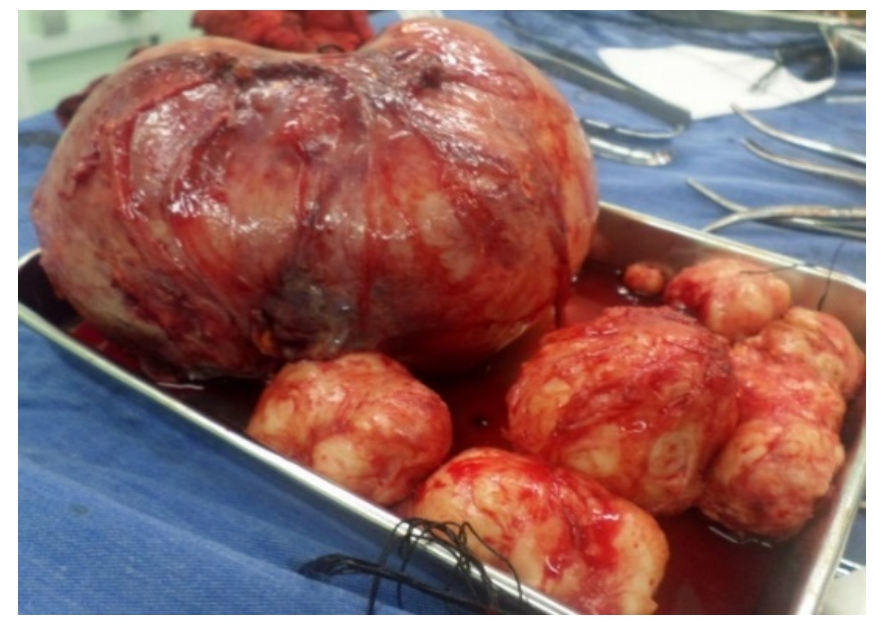

Figure 3. Anatomical parts of myomas postoperatively.

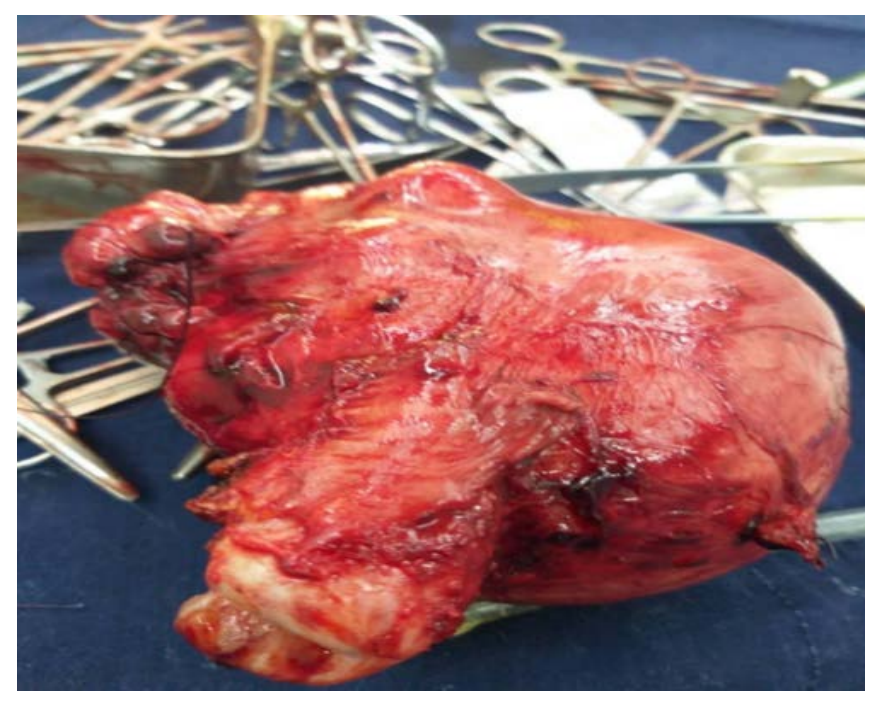

Figure 4. Anatomical part of a globular and polymyomatous uterus post hysterectomy. 


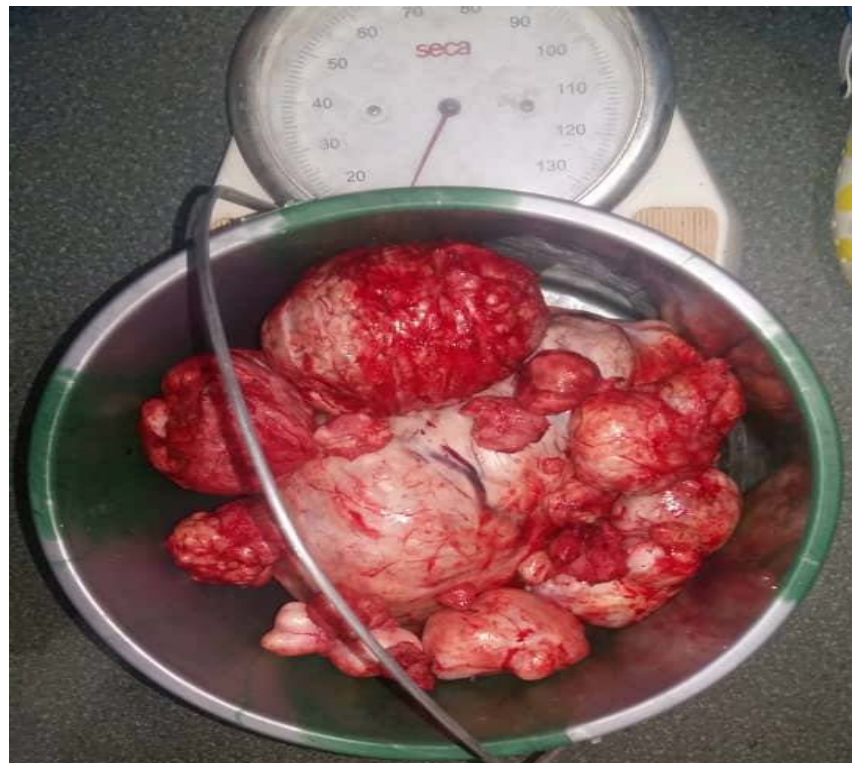

Figure 5. Evaluation of the weight of myomas postoperatively.

Nguyen-Duc H; in 2003 found out a case of GF of $13 / 10 \mathrm{~cm}$ in diameter in a 15-year-old adolescent with conservation of the uterus. [6]. llham B [7] in Morocco also pointed out a case of fibroma of $20 \mathrm{~cm}$ in diameter in a 52-year-old patient in perimenopause without uterine preservation.

Age: The age group 25 - 29 years represented 56.6\% with an average age of 35 years. These results were similar to those of Nourelhouda C. et al. [9] (35 years), and lower than those of Erghouni M. [8] who reported an average age of 41 years.

History: Nulliparous women represented $50 \%$ of our patients. These data are higher than those reported by Nourelhouda C. [9] (37.83\%). In contrast, Erghouni M. [8] reported an average parity of five (5). This difference is explained by the fact that, in our study, the patients consulted more for desire to get pregnant (34.48\%). The history of myomectomy had been found out in $20 \%$ of our patients. This rate of previous myomectomy was significantly lower than that of Nourelhouda C. et al. (71.8\%) [9]. The desire to become pregnant was the most common reason for consultation in our study (34.48\%), followed by pelvic pain (23.33\%). However, in the series of Erghouni M, all the patients had consulted for a pelvic abdominal mass [8].

Clinical data: An average delay of five years was found between the occurrence of the signs and the gynecological consultation in 53.3\% of the cases. All our patients have reported a progressive increase in abdominal volume over many years. These patients had not consulted for various reasons: the lack of a specialized unit nearby, socio-cultural reasons or even a reluctance to a possible surgery. Erghouni $M$ had figured out an average delay of 6 years for the same reasons [8].

In our study, palpation of the abdomino-pelvic mass was the most frequent clinical sign (83.33\%); which was higher than that of Erghouni M. [8] (80\%). In 
contrast, Nourelhouda C. et al. reported that genital hemorrhage was the most common sign with $35 \%$, followed by abdominopelvic mass in 16\% [9].

The uterine height ( $\mathrm{UH}$ ) between $25-29 \mathrm{~cm}$ affected $46.66 \%$ of our patients. All our patients had had pelvic ultrasound to assess the size and mapping of fibroids. The latter had highlighted: $48.6 \%$ of interstitial myomas; $32.7 \%$ subserosal and $18.54 \%$ submucosal. Nourelhouda C. et al. reported $43 \%$ subserosal; $34 \%$ submucosal and $23 \%$ intramural [9]. A complementary computed tomography was carried out in $10 \%$ of the cases for causes of mechanical compressions (hydronephrosis, disorder of the intestinal and urinary transit). However, in Erghouni M.'s study [8] all these patients had had magnetic resonance imaging (MRI) for the mapping and size of myomas. MRI is the most effective medical examination in the diagnosis of pelvic pathologies. But its cost, accessibility and its counter-indications limit its realization in our context.

Surgery myomectomy was performed in $77.67 \%$ of cases and hysterectomy in $23.3 \%$ of cases. Unlike Erghouni M. [8] who had $16.66 \%$ myomectomies and $83.34 \%$ hysterectomy. This discrepancy could be explained, in our study, by our patients consulted for desire of pregnancy. The size of the nuclei after surgery was greater than $25 \mathrm{~cm}$ in $48.66 \%$ of our patients. Our data were comparable to that of Erghouni M [8], who had found $41.66 \%$ of cases. Spinal anesthesia was the most practiced with $86.6 \%$.

The management of GFs in our study was exclusively surgical and by the abdominal route as in the literature [8] [9] [10]. Their indications took into account the complications caused by size, mechanical compression; debilitating pain and hemorrhagic pain. The type of intervention depended on several parameters. In those involving postmenopausal patients, a total hysterectomy with adnexectomy was decided in order to avoid the subsequent risk of ovarian or cervical cancer. Myomectomy has been recommended in some young patients, in order to preserve fertility (intend to get a child). All of our patients had undergone cervical cancer screening with the IVA/IVL visual inspection technique, unlike the studies cited above. Sãvulescu F et al. in Romania [11] reported a case of myoma measuring 33/28/22 cm and weighing $18.1 \mathrm{~kg}$.

Data and post-operative care: We found out a weight of the nuclei between 1 and $5 \mathrm{~kg}$ in $80 \%$ of the cases. The size of the fibromatous nuclei and or the uterus measuring more than $25 \mathrm{~cm}$ after surgery was reported in $48.66 \%$ of patients. Some of our patients, even a bulky and polymyomatous uterus, wanted to keep the uterus for reasons of fertility. The blood transfusion had concerned $26.6 \%$ of the patients among them, in $43.33 \%$ was transfused in per and or post operatively. Operative complications were dominated by hemorrhages in $20 \%$ of cases. Bleeding remains one of the early complications of myomectomies as described by Legendre G. [12] et al., and Foulot H. et al. [13]. All of our patients had received preventive anticoagulant therapy 8 hours after surgery. We have not observed any deaths.

Histology: Leiomyoma was the histological tissue found in all cases of myomectomy as in other studies [8] [9] [10] [11]. The average length of hospital stay 
was three to five days. The patients were followed 12 months postoperatively, due to one outpatient visit per month.

\section{Conclusion}

The giant fibroid (GF) is a common cause of myomectomies. Desire to become pregnant and menstrual cycle disorders are the leading indications for these myomectomies. Hysterectomy should be reserved for the etiologies: excessive volume of fibroids, postmenopausal women and multiple gravida.

\section{Author Approval}

All the authors agree to the submission of this article.

\section{Consent}

For this work, we have received the patient's approval; that of the head of the service and the director of Hôpital du Mali.

\section{Conflicts of Interest}

The authors have declared no conflicts of interest.

\section{References}

[1] Okogbo, F.O., Ezechi, O.C., Loto, O.M. and Ezeobi, P.M. (2011) Uterine Leiomyomata in South Western Nigeria: A Clinical Study of Presentations and Management Outcome. African Health Sciences, 11, 271-278.

[2] Baird, D.D., Dunson, D.B., Hill, M.C., Cousins, D. and Schectman, J.M. (2003) High Cumulative Incidence of Uterine Leiomyoma in Black and White Women: Ultrasound Evidence. American Journal of Obstetrics \& Gynecology, 188, 100-107. https://doi.org/10.1067/mob.2003.99

[3] Racinet, C. (2009) Epidemiology, Risk Factors and Symptomatology of Uterine Myomas. MT Reproductive Medicine Gynecology Endocrinology, 11, 118-122.

[4] Flake, G.P., Andersen, J. and Dixon, D. (2003) Etiology and Pathogenesis of Uterine Leiomyomas: A Review. Environmental Health Perspectives, 111, 1037-1054. https://doi.org/10.1289/ehp.5787

[5] Wallach, E.E. and Vlahos, N.F. (2004) Uterine Myomas: An Overview of Development, Clinical Features and Management. Obstetrics \& Gynecology, 104, 393-406. https://doi.org/10.1097/01.AOG.0000136079.62513.39

[6] Nguyen-Duc, H. (2003) Large Uterine Fibroid in a 15-Year-Old Adolescent Giant Myoma in Adolescence. Journal de Gynécologie Obstétrique et Biologie de la Reproduction, 32, 748-750.

[7] Boughaza, I., Mhamd, O., Berrada, T., Zeraidi, N., Baidada, A. and Kharbach, A. (2017) Souissi Maternity Hospital, Ibn Sina University Hospital, Rabat Morocco: Giant Fibroma about a Case. Moroccan Journal of Medical Sciences, 21, 56-58.

[8] Meryem, E. (2017) Rhajdi: Giant Myomas; Special Features and Treatment for 12 Cases; Fez (Morocco). Thesis of Medicine N 128/2017, Faculty of Medicine and Pharmacy of Fes. Morocco.

[9] Chalal, N. and Demmouche, A. (2013) Epidemiological Profile of Uterine Fibroids 
in the Region of Sidi Bel Abbes. Algeria Pan African Medical Journal, 15, 7. https://doi.org/10.11604/pamj.2013.15.7.2690

[10] Brun, J.L., Legendre, G., Bendifallah, S. and fernandez, H. (2013) Myomectomy. Press Med.; Elsevier Masson SAS.

[11] Sãvulescu, F., Iordache, I., Albiåa, O., Hristea, R., Dumitru, C., Iordache, A., Bãlaæa, G., Iordache, C., Leau, D., Rogin, T. and Vîrjoghe, V. (2011) Giant Uterine Leiomyoma. Chirurgia (Bucharest, Romania: 1990), 106, 665-668. https://www.researchgate.net/publication/51874451

[12] Legendre, G., Brun, J.L. and Fernandez, H. (2011) Place Myomectomies in Spontaneous Conception or in Women Wishing to Preserve Their Fertility. Journal de Gynécologie Obstétrique et Biologie de la Reproduction, 40, 875-884. https://doi.org/10.1016/j.jgyn.2011.09.023

[13] Foulot, H., Chopin, N., Malartic, C., Fauconnier, A. and Chapron, C. (2005) Myomectomies by Laparotomy. EMC-Obstetrics Gynecology, 2, 377-383. https://doi.org/10.1016/j.emcgo.2005.08.001 


\section{Individual Investigation Sheet}

File number:

Date of consultation:

.$/ 2017$

CIVIL STATUS OF THE PATIENT

Q1: First and last name:

Q2: Age:

Q3: Gender: $\square$ Female

Q4: Profession

$\square$ Civil servant

$\square$ Economic operator

$\square$ saleswoman

$\square$ Worker

$\square$ Housewife

$\square$ Pupil/Student

$\square$ Others

Q5: Ethnic group
Bambara
$\square$ Peulh
$\square$ Dogon
$\square$ Malinké
$\square$ Sonrhaï
$\square$ Soninké

$\square$ Other to be specified

Q6: Residence

$\square$ District $\quad \square$ out of district

Q7: Nationality

$\square$ Malian $\square$ Other to be specified

Q8: Reason for consultation
$\square$ Pelvic pain
$\square$ Metrorrhagia
$\square$ Metro menorrhagia
$\square$ Menorrhagia
$\square$ Hemorrhage
$\square$ Leucorrhea
$\square$ Urinary sign
$\square$ Mass perception
$\square$ Desire for pregnancy

$\square$ Gynecological examination for other reasons $\square$ Emergency

Q9: History

Medical:

$\square$ HBP $\square$ Diabetes $\quad \square$ Anemia

$\square$ Other specified

........

Surgical

$\square$ Cesarean section $\quad \square$ Polymyomectomy $\quad \square$ Salpingotomy

$\square$ Other to be specified

Families:
$\square$ HBP
$\square$ Diabetes

$\square$ Other to be specified

Obstetrics:

Gestity ..... Parity ..... Living ..... Dead ..... Termination of pregnancy ..... $\square$ Inter-reproductive interval

Gynecological:

Menstruation: $\quad \square$ regular $\quad \square$ irregular

Duration of menstruation

Dysmenorrhea: $\quad \square$ Yes $\quad \square$ No

Dysuria: $\quad \square$ Yes $\quad \square$ No

Menarche ............ years

Date of last menses (DLM) ..... 
Q10: Clinical examination

\begin{tabular}{|c|c|c|c|}
\hline General condition: & $\square$ good & \multicolumn{2}{|r|}{$\square$ deteriorate } \\
\hline Conjunctivitis: & $\square$ colored & \multicolumn{2}{|c|}{$\square$ moderately colored $\quad \square$ pale } \\
\hline Uterus size: & $\square$ increased & \multicolumn{2}{|c|}{$\square$ normal } \\
\hline \multicolumn{4}{|c|}{ Uterine height (measuring tape): ........ } \\
\hline \multicolumn{4}{|l|}{ Q11: Ultrasound } \\
\hline Subserosal fibroma: & $\square$ Yes & $\square$ No & \\
\hline Mucosal fibroma: & $\square$ Yes & $\square$ No & \\
\hline Intramural fibroma: & $\square$ Yes & $\square$ No & \\
\hline \multicolumn{4}{|c|}{ Q12: Associated signs } \\
\hline Urinary: & $\square$ Yes & $\square$ if yes to be & specified . \\
\hline Digestive: & $\square$ Yes & $\square$ if yes plea & specify ........ \\
\hline Pregnancy: & $\square$ Yes & $\square$ if yes, spec & fy $\ldots \ldots \ldots \ldots$ \\
\hline \multicolumn{4}{|c|}{ Q13: Associated pathologies } \\
\hline Ovarian cyst: & $\square$ Yes & $\square$ No & \\
\hline Cancer & $\square$ Yes & $\square$ No & \\
\hline -Endometriosis: & $\square$ Yes & $\square$ No & \\
\hline -Anemia: & $\square$ Yes & $\square$ No & \\
\hline \multicolumn{4}{|c|}{ Q14: Additional examinations } \\
\hline -Ultrasound: & $\square$ Yes & $\square$ No & \\
\hline \multicolumn{4}{|l|}{ Result ......... } \\
\hline GnRH: & $\square$ Yes & $\square$ No & \\
\hline
\end{tabular}

-Anterior laparoscopy less than 2 years:

$\square$ Yes $\quad \square$ No

Result

CBC:

$\square$ Yes

$\square$ No

Result

Other

Q15: Treatment

Medical: $\quad \square$ Yes $\quad \square$ No

If Yes specified:

Q16: Preoperative anesthesia report

Blood transfusion: $\square$ pre-op $\square$ per-op $\square$ post-op

Q17: Type of anesthesia:

$\square$ general anesthesia $\square$ Spinal anesthesia

Q18: Type of incision

$\square$ Pfannenstiel $\quad \square$ Medline

Q19: Operational difficulties

Anesthesia: $\square$ HBP $\square$ Hypotension

$\square$ Anesthetic conversion

Bleeding: $\quad \square 200 \mathrm{cc} \quad \square 300 \mathrm{cc}$

Trauma/operational incident: 


\section{$\square$ bladder trauma \\ $\square$ Rectal trauma \\ $\square$ Tubal trauma}

Q 20: Number of surgeons:

$\square$ two $\square$ three

Q21: intraoperative clinical evaluation:

Size of the uterus: $\mathrm{cm}$

Number of nuclei:

Topography of the nuclei:

$\square$ serosal ..... $\square$ muscular .... $\square$ mucosal ......

Q 22: Nature of uterine incision:

$\square$ horizontal $\square$ vertical

Q23: Status of the appendices:

$\square$ tubes

$\square$ Ovaries

Q 24: Hysterectomy $\square$ Yes

$\square$ no

$Q$ 25: Duration of the intervention
$\square 2$ hours
$\square 3$ hours
$\square 4$ hours
$\square 5$ hours

Q 26: Post-operative complications:

Anemia:

$\square$ Yes

$\square$ No

Thromboembolic disease:

$\square$ Yes $\quad \square$ No

Suppuration: $\quad \square$ Yes $\quad \square$ No

Q 27: Duration of hospitalization:
$\square 3$ days
$\square 4$ days
$\square 5$ days
$\square$ 10days
$\square 20$ days

$\square$ Other specified ......

Q 29 histological examination of the operating room:

Result: 